\title{
A New Direction or Another False Dawn? David Cameron and the Crisis of British Conservatism
}

\author{
Peter Dorey \\ Cardiff School of European Studies, Cardiff University, Cardiff CF10 3XQ, UK. \\ E-mail: Dorey@cf.ac.uk
}

\begin{abstract}
After three successive general election defeats, and three leaders since 1997, the Conservative Party finally seems to have staged a recovery during the first year of David Cameron's leadership. He has energetically sought to reposition the Conservatives ideologically, insisting on the need to depart from Thatcherism and move back towards the centre ground of British politics by promoting a more socially inclusive and compassionate Conservatism. His initial efforts seem to have been highly successful, with the Conservative Party enjoying its first sustained poll leads over Labour since 1992. However, more careful consideration suggests that the Conservative's recovery is rather fragile, and thus far dependent mainly on short-term factors. Certainly, the Party should be (and needs to be) much further ahead in the polls at this stage of the electoral cycle if it is to win the next general election. Moreover, Cameron has deliberately avoided making specific policy pledges so far, pending a comprehensive internal policy review to be completed by the summer of 2007, yet when more detailed policies are announced many of them are likely to refuel intra-party divisions between socially liberal modernizers and Thatcherite traditionalists, and this, in turn, will almost certainly alienate some of the electoral support (re)gained during Cameron's first year as Conservative leader. Consequently, a Conservative victory at the next general election remains highly unlikely.
\end{abstract}

British Politics (2007) 2, 137-166. doi:10.1057/palgrave.bp.4200051

Keywords: David Cameron; modernization; ideological repositioning; one nation Conservatism; poll ratings

No-one can say quite how many people vote Conservative, not for the love of Conservatism, but for dislike of the other side. The 'other side' may change.

(Blake, 1985, 368)

\section{Introduction}

It is widely acknowledged that the Conservatives were Britain's most successful political party during the 20th century, hence the notion that this constituted the 'Conservative century' (Seldon, 1994; see also Ramsden, 1999, 7-8). Between the general elections of 1874 and 1997, the Conservatives were in 
office for 84 out of 123 years, either governing alone, or as the dominant partner in a coalition government (Wheatcroft, 2005, 21), during which time it won three consecutive general elections in the 1950s, and four successive elections from 1979. Consequently, the Conservatives 'developed... a strong identity as the party of government because they have generally been the party in government' (Gamble, 1974, 10).

Yet, having thus dominated British politics for so much of the 20th century, and appearing virtually invincible during the 1980s, the Conservative Party has only recently begun to recover from its remarkable political collapse in the 1990s (for the factors leading to this collapse, which are beyond the remit of this paper, see Gilmour and Garnett, 1997; Critchley and Halcrow, 1998, 37-40; Dorey, 1999; Wheatcroft, 2005). After subsequently floundering in the political wilderness for the last 10 years - having underestimated the durability and tenacity of Tony Blair and New Labour, and being uncertain as to how it should respond ideologically - the election of David Cameron finally appears to have heralded a revival in Conservative Party fortunes to the extent that many in the Party now envisage victory in the next general election. However, this article will urge caution by suggesting that the recovery of the Conservatives during the last year has been fragile and, as yet, unconvincing. The first part of the article will look at Cameron's efforts at repositioning the Conservative Party ideologically, thereby explicitly disavowing Thatcherism in favour of a socially liberal 'one nation' mode of Conservatism. This section will also note the sources of hostility and opposition within the Party to Cameron's modernizing agenda, and suggest that, as more specific policies are unveiled during the next 2 years, this hostility is likely to increase and become more focused, particularly if the ensuing policies genuinely reflect a socially liberal or compassionate Conservatism in accordance with Cameron's pronouncements to date. The second section will briefly consider Cameron's efforts at making the Party more socially representative and electorally attractive by recruiting more women and ethnic minority candidates, a strategy which has also aroused considerable opposition from some quarters of the Party. The third section will examine the Conservative Party's recovery in the opinion polls during 2006, noting that the poll leads enjoyed during the first year of Cameron's leadership have not been sufficiently large or consistent to suggest that victory in the next general election is probable. Indeed, we will note that Labour often enjoyed poll leads over the Conservatives during the 1980s and in 1990-1991, but saw these dissipate once the general election itself was held. Moreover, by the time the next general election takes place, Tony Blair will no longer be Prime Minister, and the Iraq war may well be less salient as an issue, which means that two major sources of current Labour unpopularity are likely to have been 'neutralized'. The paper will thus conclude by arguing that, while David Cameron has made valiant efforts at modernizing the Conservative Party and 
steering it back to the centre ground, thereby yielding a modest recovery in the opinion polls, his Party's recent popularity remains modest and insufficient to deliver victory in a general election. Furthermore, this revival is likely to be undermined if the eventual unveiling of more specific policies leads to renewed intra-party dissent and disagreement between Conservative modernizers and Thatcherite traditionalists.

\section{David Cameron's election as Conservative leader}

As Denham and O'Hara have noted (2007), David Cameron won the Conservative's 2005 leadership contest having pledged that he would 'modernize' the Conservative Party in a rather different manner to his leadership rivals. Cameron's vision of Conservative 'modernization' entailed a break with Thatcherism, in order to render the Party more socially liberal and inclusive in its ideological orientation and policies, and more socially representative in its composition and parliamentary personnel. While Cameron's three predecessors had also espoused greater social tolerance and inclusiveness during the early parts of their respective leaderships, none had appeared particularly comfortable or convincing in their advocacy of such an approach, and as such, it was perhaps not too surprising that each had readily tracked back to the Right when the opinion polls failed to indicate any increase in the Conservative Party's popularity (see, e.g., Dorey, 2002, 2003, 2004).

Somehow, Cameron appeared genuine and heartfelt in his advocacy of 'compassionate Conservatism' (although some critics argued that his previous voting record in the House of Commons was at odds with this stance, while also recalling that George $\mathrm{W}$. Bush too had originally sought to portray himself as a 'compassionate conservative'). Moreover, it was noted that for all his professed desire to preside over a more socially diverse and representative parliamentary party, Cameron had been a key author of the Conservative Party's 2005 manifesto, in which asylum, immigration and Euro-scepticism had featured prominently (Freedland, 2005). Although Cameron was sometimes derided for his somewhat 'upper class' background (educated at Eton and Oxford, and married to the daughter of a landowner, and whose step-father is Viscount Astor) - the implication being that he is 'out of touch' with ordinary British people - Cameron was redolent of the 'one nation' strand of Conservatism which had appeared otiose during the Thatcher years (Dorey, 1996), but which nonetheless had a long and venerable history in the annals of the Conservative Party. This mode of Conservatism, often emanating from its aristocratic or 'grandee' members, and closely associated with paternalism and noblesse oblige, was rather more socially progressive in its attitude, and consensual in its approach (for an excellent characterization of 'Tory 
paternalism' see Greenleaf, 1983, chapter 7; see also Eccleshall, 1990, chapter 6; Green, 2005), than other variants of Conservatism, particularly the petit bourgeois 'moral economy' and social authoritarianism which underpinned much of Thatcherism (see, e.g., Hall et al., 1978; Hall 1980; Bechhofer and Elliott, 1981, 189-193; Gamble, 1988).

From the outset of his leadership victory, therefore, David Cameron was likely to encounter residual opposition to his modernizing agenda from those in the Party who continued to subscribe to the 'moral economy' of the provincial middle class, and who, therefore, did not share Cameron's own apparent liberal cosmopolitanism and Notting Hill niceties. Indeed, as Denham and O'Hara note in their article in this volume, a YouGov poll published at the same time as Cameron's election to the Conservative leadership revealed that while $45 \%$ of its mass membership wanted the Party to move to the centre, $48 \%$ of grass-roots Conservatives preferred a more Right-wing approach which would place 'clear blue water' between them and the Labour Party. How and why David Cameron succeeded, therefore, in securing the support of $68 \%$ of the Conservative Party's extra-parliamentary membership is a conundrum which is beyond our remit here (for an account of the 2005 Conservative leadership contest, see Denham and Dorey, 2006).

As also noted in Denham and O'Hara's article, Conservative 'modernization' has invariably enshrined three dimensions: leadership, policies and organization. Our primary concern in this article is to examine Cameron's stance on the twin issues of ideological repositioning and policy modernization, before proceeding to discuss his parallel attempts at 'modernizing' the Conservative Party itself, primarily through widening recruitment to render it more socially representative. Both topics will also entail consideration of the controversies and sources of opposition engendered by these attempts at modernization, for these will impact both on Cameron's own degree of success in 'modernizing' the Conservative Party, and on the extent to which the British electorate is persuaded that the Conservatives have genuinely been reformed into a more attractive and credible centre-right party - one which is ready to offer constructive measures for the problems facing Britain in the early $21 \mathrm{st}$ century, rather than a 'nasty party' still obsessed with fighting the battles and perceived adversaries of the 1980s.

\section{Ideological Repositioning and Policy Modernization}

Although Cameron's leadership campaign had placed considerable emphasis on the need for the modernization of British Conservatism, few could have anticipated just how bold and innovative some of his ideological pronouncements and associated policy stances subsequently proved to be. Certainly, Cameron went rather further than his three predecessors in instigating a sharp 
break with Thatcherism, and, instead, fostering a more socially tolerant and inclusive Conservatism. Moreover, he was emphatic that he would not be deflected - or deterred - from pursuing this approach, partly because he seemed genuinely and wholeheartedly to believe in it, but also because Cameron clearly recognized that with the next general election probably at least 3-4 years away the electorate would only be persuaded that the Party's transformation was genuine if it was sustained on a long-term basis. Such persuasion was essential both to regain the trust and support of former Conservative voters (who had become disillusioned with the Party during the Thatcher-Major years), and to attract electoral support from hitherto nonConservatives who had similarly become increasingly disillusioned with New Labour's performance in office.

With regard to the latter, for example, the final Blair Government increasingly struggled to convince the electorate that its NHS reforms were working, particularly as much of 2006 and early 2007 was dominated by media reports of NHS Trusts' deficits accompanied by ward closures and staff redundancies in many of Britain's hospitals, coupled with complaints by health service workers about excessive bureaucracy and layers of management in the NHS. The same period witnessed a series of crises afflicting the Home Office, particularly with regard to the politically sensitive issues of crime and immigration. Much crime reportage throughout 2006 was concerned with a series of fatal stabbings arising from the entrenchment of a 'knife culture' among parts of Britain's youth underclass, but by the beginning of 2007 it was fatal shootings among rival urban gangs that were dominating the headlines. During the same period, the Home Office was embroiled in a series of damaging revelations, including: the release of more than 1,000 foreign prisoners who were freed without being considered for deportation first; a failure to record, on a national criminal database, details of crimes committed by British citizens abroad; overcrowding in Britain's jails as the prison population exceeded 80,000 for the first time ever (leading the Home Secretary, John Reid, to urge judges to impose fewer custodial sentences on non-violent offenders due to a lack of capacity for further prisoners); and a predicted $£ 350$ million shortfall in the Home Office's prison-building budget. Such crises led Reid himself to acknowledge to the parliamentary home affairs select committee that the Home Office was 'not fit for purpose', to the extent that its separation into a Department of Security (covering immigration and counter-terrorism) and a Ministry of Justice was proposed. Such crises seriously damaged New Labour's erstwhile neutralizing of the Conservative's traditional political advantage and electoral lead on issues concerning lawand-order and immigration, and doubtless contributed to the increasing alienation of many voters who had supported New Labour since 1997, but were now more receptive to the appeal of an apparently reformed Conservative Party. 
A new political leader's efforts at modernizing their party in terms of policies is often manifested at three discrete but logically sequential levels: the macrolevel, which relates, in this context, to the overall ideological position that the leader is seeking to adopt, and which will thus provide the philosophical or normative framework of policy development; the meso-level, entailing general statements of principle or intent vis-à-vis key sectors or spheres of policy, such as crime, environment and the family; and the micro-level, entailing concrete proposals for specific policies in these particular spheres. There is thus a funnel effect on policy modernization, whereby declarations pertaining to overall ideological position and orientation filters down into a corresponding stance on broad areas of policy, before narrowing down into specific policies. Usually, during the first year or two of a new leader's tenure, policy modernization is confined primarily to the macro- and meso-levels, with micro-level policies tending to emerge from the second year onwards. Or, as David Cameron himself has explained it, party modernization is like building a house: 'First you prepare the ground, then you lay the foundations. And then finally, brick by brick, you build your house' (The Observer, 1 October 2006).

There are three main reasons for this type of approach. Firstly, a new leader will often need at least a year, often two, to reposition their party ideologically, and thereby define its new or modified political stance. The exact length of time will depend largely on the extent to which the new leader possesses a clear vision of how they wish to reposition their party, and the scale of support or opposition in the party to such modernization. Secondly, a new leader's first year or two will often, pari passu, entail a formal internal review of party policies, especially if the new leader has been elected in the aftermath of a general election defeat (such as the major and lengthy policy review undertaken when Edward Heath replaced Sir Alec Douglas-Home as Conservative leader in 1965), which means that on many issues, the leadership will be unable to offer specificities during the early stages of their leadership. Thirdly, specific policy pledges, which are made too early (notwithstanding the prior need to reposition their party ideologically and politically), are almost certain to be 'costed' by government Ministers who will then denounce them for being 'unaffordable' or for being likely to have dire consequences. Alternatively, if an opposition leader and their party do offer specific policy pledges too early in the lifetime of a Parliament, and these prove popular with the public, Ministers are likely to adopt or adapt these policies themselves, and thereby neutralize the potential threat posed by their political opponents.

In Cameron's case, the macro-level of policy modernization has been characterized by an explicitly avowed departure from Thatcherism, which he deems no longer appropriate to addressing the most important or salient issues during the first decade of the 21st century and beyond. Cameron has signalled this departure in two ways. Firstly, by clearly asserting the need for a new 
mode of Conservatism, one which is socially tolerant and compassionate, embraces cultural diversity and pluralism, and is consequently located near or on the 'centre ground', which the Party will thus seek to wrest from New Labour. Secondly, by openly disavowing particular policy stances adopted by the Thatcher Governments during the 1980s and acknowledging that these were, at least with the benefit of hindsight, unnecessary or unwise.

In terms of signalling the departure from Thatcherism through the explicitly expressed need for a new mode of compassionate and socially inclusive Conservatism, Cameron has asserted, right from the outset of his leadership, that: 'At the next election, a whole generation of people will be voting who were born after Margaret Thatcher left office. So when it comes to tackling the big challenges our society faces, I won't be the prisoner of an ideological past' (The Independent, 2 January 2006). Instead, Cameron has constantly reiterated the need to reposition the Conservative Party on the centre ground of British politics, for as he explained to delegates at the Party's 2006 conference, this is 'the ground on which political success is built... Not some bog on the fringes of debate' (The Times, 2 October 2006).

To this end, David Cameron has insisted, on various occasions, that 'there is such a thing as society, but it is not the same thing as the state'. Indeed, the phrase also appears in the introduction to the Built to Last statement of Conservative aims and values (Conservative Party, 2006), which encapsulated Cameron's modernizing agenda and was intended to provide the context for the policy reviews undertaken during 2006 (see below). The repeated deployment of the phrase is (deliberately) significant and symbolic, because Margaret Thatcher famously declared that there was 'no such thing as society' (although it is often overlooked that she did immediately refer to the existence and vital role of families and communities). For many people, this phrase (albeit perhaps misinterpreted or taken out of context) came to symbolize the rampant individualism, nihilism, selfishness and 'greed is good' ethos of Thatcherite Britain during the 1980s, and as such, Cameron's repeated insistence that 'there is such a thing as society' is widely interpreted - just as he doubtless intends it to be - as an explicit repudiation of Thatcherism.

With regard to disavowing particular policy stances adopted during the 1980s (thereby exemplifying the professed break with Thatcherism), there has, for example, been an explicit expression of contrition over the treatment of public sector employees during the 1980s, with an interim report from the public sector improvement group (one of several policy review groups established by David Cameron) candidly admitting that the previous Conservative administration had subjected public services to excessive 'audits' and inspections — 'this approach has run its course' — and exaggerated the extent to which they could and should mimic the private sector. It was now recognized that 'a private corporation which publicly shamed its employees in 
the way that government has done in recent years would not long survive', and hence the new approach was to be one of seeking a partnership with public sector professionals (Perry and Dorrell, 2006, 4). A similarly conciliatory approach was evident in Cameron's own call for an end to the 'permanent revolution' and 'pointless reorganizations' in the NHS (The Guardian, 23 January 2007), and his pledge that when essential changes were introduced into the public services, they would evince 'deference to the manners and customs of the people who work in the public services and the people who use them' (The Guardian, 26 January 2007). Meanwhile, David Willetts, the shadow education secretary, has declared that: 'We want to raise... standards by working with the professions, not beating up on them' (The Guardian, 6 September 2006).

Indeed, as David Sanders notes in a recent edition of this journal, a more constructive and consensual approach to the public sector could prove beneficial for David Cameron's Conservatives, because of the extent to which: 'Workers in this sector are ripe for conversion to any party which promises with conviction - to reduce the target/monitoring/audit burden... inflicted upon them', and as such, the discontent experienced by public sector workers 'could be converted into an important electoral asset for the Conservative Party ... a tremendous political opportunity' (Sanders, 2006, 179).

Another major policy from the Thatcher-Major era for which a virtual apology has been issued during the first year of Cameron's leadership is the privatization of the railways. Although this policy was enacted in 1996 by John Major's disintegrating Conservative Government, it has become widely viewed as symbolic of the dogmatic pursuit of Thatcherite ideology pushed to its destructive limits. Thus has Tim Grayling, the Conservative's transport spokesperson, acknowledged that, with hindsight, the separation of track and trains into separate businesses at the time of privatization had proved to be a mistake, and that what was now needed was 'a much greater degree of integration between track and train', although he emphatically ruled out a direct return to public ownership (The Daily Telegraph, 17 July 2006).

David Cameron has also apologized to the citizens of Scotland for the Thatcher Government's treatment of them as 'guinea pigs' for the poll tax, which was implemented north of the border (in 1989) a year before being introduced in England and Wales. He candidly confesses that: A series of blunders were committed in the 1980s and 1990s, of which the imposition of the poll tax was the most egregious... . The decision to treat Scotland as a laboratory for experimentation in new methods of local-government finance was clumsy and unjust'. In this context, Cameron has acknowledged the existence of 'English cultural insensitivity' towards Scotland and its citizens (The Scotsman, 16 September 2006).

Cameron has also admitted that the Conservative Party 'got it wrong' in its approach to the apartheid regime in South Africa, for while there had been 
widespread international support for an economic and cultural boycott of South Africa until apartheid was abolished and Nelson Mandela (a leader of the anti-apartheid African National Congress) freed from prison, Margaret Thatcher famously opposed such a boycott, arguing that it would harm South Africa's black population more than anyone else. Meanwhile, some young Conservatives displayed their shared concern for the victims of apartheid by ostentatiously wearing a 'Hang Nelson Mandela' t-shirt. Fast forward 20 years, and David Cameron acknowledged 'the mistakes my party made in the past with respect to... sanctions on South Africa', adding that Nelson Mandela and the African National Congress (accused by Thatcher of being 'terrorists') should take much of the credit for the fact 'that there is so much to celebrate in the new South Africa' (The Observer, 27 August 2006).

Cameron reiterated his departure from previous Thatcherite policy stances when he informed delegates at the Conservative's 2006 conference that the days when the Party preoccupied itself with issues such as Europe, restoring grammar schools, promoting private healthcare and prioritizing tax cuts over improving public services should be gone forever, for the concerns which people had in 21 st century Britain were not the same as those which prevailed in the 1980s (The Times 2 October 2006).

At the meso-level of policy modernization, Cameron's attempt at forging a new mode of progressive and socially concerned Conservatism has been evident in the principles and aspirations articulated with regard to broad areas of policy, such as employment, and the environment. For example, Cameron has placed an unprecedented (for any political leader in Britain) emphasis on 'quality of life' issues, one of the most important of which is securing a 'work-life balance'. In stark contrast to the rampant materialism and conspicuous consumption of Thatcherism during the 1980s, Cameron declared that there was more to life than merely making and spending money, to the extent that 'general well-being' ought to be viewed as more important than the possession of material goods and wealth. With echoes of Ronald Inglehart's (1960s) thesis about the rise of post-materialism in Western society, Cameron urged greater appreciation of the cultural aspects of life, and greater emphasis on the intrinsic worth and social benefits of good personal relationships: 'It's time we admitted that there's more to life than money, and it's time we focused not just on GDP but on GWB general well-being... . Improving our society's sense of well-being is...the central political challenge of our times' (The Times, 22 May 2006).

To this end, Cameron urged the development of greater flexibility in the workplace, in order that a better 'work-life balance' could be pursued, and family life be imbued with a practical impetus, although he was also adamant that this could only be achieved by voluntary means, rather than prescriptive statutory measures. Nonetheless, this was a markedly different type of 'flexibility' to that promoted by Thatcherism and New Labour alike, for 
whom 'flexibility' was invariably a euphemism for obliging employees to work longer or more unsocial hours, rather than a means of enabling working people to tailor their employment in a manner which enabled them to spend more time with their partners and/or children. In so doing, Cameron was also rendering more meaningful the Conservative Party's traditional emphasis on the importance of the family as a social institution, for Britain's long or unsocial working hours have increasingly made it difficult for parents to spend time with each other and their children (something which Thatcherite Conservatives and their New Labour successors have never really comprehended).

Cameron's emphasis on 'quality of life' issues also manifested itself in his professed concern about environmental issues, most notably climate change and global warming. He warned delegates at the Conservative's 2006 conference that: 'Going green is not some fashionable, pain-free option. It will place a responsibility on business. It will place a responsibility on all of us'. In this context, Cameron has called for annual reductions in carbon emissions, and urged a new bipartisan, consensual, approach to developing 'urgent' measures to tackle climate change, insisting that the environment is too important to be left to party politics and short-term electoral considerations (Cameron, 2005). The Conservative leader has also praised the work of Friends of the Earth in promoting measures to tackle climate change. Moreover, Cameron appointed Zac Goldsmith, editor of The Ecologist magazine (and a prominent anti-globalization, anti-nuclear campaigner) to co-chair his 'Quality of Life' policy review group.

Another policy area where a radical break with Thatcherism is evident concerns the new Conservative approach to poverty and social exclusion. Considerable effort has been expended presenting Cameron's Conservatives as the Party which will focus on the 'dispossessed' in British society. Acknowledging that the Conservatives have hitherto been widely viewed as being concerned primarily with 'those who can look after themselves, or the rich', Oliver Letwin (Cameron's co-ordinator of policy modernization) has claimed that 'the focus of modern compassionate conservatism... is on those most in need ... the unemployed, the homeless, the disabled, the refugee, the orphan, the drug addict' (The Times, 17 March 2006; see also speech by Michael Heseltine, on tackling urban deprivation, cited in The Guardian, 8 April 2006).

Elsewhere, Cameron urged a less punitive approach in the Conservative Party's stance on crime and anti-social behaviour. Instead, he has called for greater understanding both of the socio-economic circumstances in which crime seems to flourish, and of the individuals who engage in anti-social or criminal behaviour. In a speech on youth crime to the Centre for Social Justice think-tank in July 2006, for example, Cameron referred to the recent moral panic over young people wearing hooded tops and argued that: 'The "hoodie" is a response to a problem, not a problem in itself. We - the people in suits often see hoodies as aggressive, the uniform of a rebel army of young 
gangsters...[But]... When you see a child walking down the road, hoodie up, head down, moody, swaggering, dominating the pavement - think what has brought that child to that moment'. Cameron insisted that rather than resorting to short-term palliatives and tabloid-pleasing initiatives such as ASBOs and curfews on young people, society needed to address the underlying causes of anti-social behaviour and criminality, while also being prepared 'to show a lot more love' towards teenagers from troubled or dysfunctional backgrounds (the Daily Telegraph, 10 July 2006). Cameron has reiterated these arguments on various occasions subsequently (see, e.g., The Times, 3 November 2006), thereby disregarding the jibes from incredulous Right-wing Conservative critics and bemused senior Labour Ministers alike about his 'hug a hoodie' approach to tackling youth crime and delinquency, and Labour's allegations that Cameron's Tories were 'soft on crime'.

Finally, Cameron appears to be much more relaxed and tolerant than his predecessors on such issues pertaining to sexual orientation and lifestyles, to the extent of supporting the 2004 Civil Partnerships Act (granting legal recognition to same-sex relationships or 'gay marriages'), and insisting — in front of delegates at the Conservative's 2006 conference, many of whom were visibly aghast - that marriage means something special, 'whether you're a man and a woman, a woman and a woman or a man and another man'.

In certain respects, Cameron's approach to discrete policy areas is also notable for what has not been said or emphasized. In particular, Conservative modernizers have made relatively little reference so far to issues such as asylum, immigration or the European Union. While such avoidance infuriates the Party's Right, Cameron and other Conservative modernizers recognize that it was the previous emphasis on these issues (along with repeated denigration of unmarried mothers) that sustained public perceptions of the Conservatives as 'the nasty Party'. Moreover, these issues have generally been of low salience to voters in recent general elections, so that the Conservative's emphasis on them yielded few electoral dividends beyond shoring up the Party's 30-31\% core vote. Furthermore, the divisiveness of the EU as a policy issue for the Conservatives has previously been a significant factor fuelling public perceptions of Party disunity, and this has reinforced Cameron's determination to avoid, as far as practicably possible, the EU as a policy issue (aided, of course, by the Blair Government's indefinite postponement of referenda on British membership of the euro, and the draft EU constitution).

As already noted, Cameron's leadership has so far been characterized by a relative paucity of specific policies on particular issues, for reasons noted above. Instead, the focus has been on effecting an explicit shift away from Thatcherism, and the enunciation of a new stance with regard to broad spheres of policy. Thus did Cameron's election as Conservative leader herald the establishment of six policy review groups, as illustrated in Figure 1. 


\begin{tabular}{|c|c|c|}
\hline Title & Policy issues & Chair(s) \\
\hline $\begin{array}{l}\text { Economic } \\
\text { Competitiveness }\end{array}$ & $\begin{array}{l}\text { - Deregulation } \\
\text { - Higher education and skills } \\
\text { - Pensions } \\
\text { - Public sector efficiency } \\
\text { - Science, technology, engineering } \\
\text { and mathematics } \\
\text { - Transport } \\
\text { - Energy }\end{array}$ & $\begin{array}{l}\text { John Redwood } \\
\text { Simon Wolfson }\end{array}$ \\
\hline $\begin{array}{l}\text { Public Services } \\
\text { Improvement }\end{array}$ & $\begin{array}{l}\text { - Health } \\
\text { - Education } \\
\text { - Social Care } \\
\text { - Social Housing } \\
\end{array}$ & $\begin{array}{l}\text { Baroness Perry } \\
\text { Stephen Dorrell }\end{array}$ \\
\hline Quality of Life & $\begin{array}{l}\text { - Climate change } \\
\text { - Energy } \\
\text { - Food, Farming, } \\
\text { Rural Affairs } \\
\text { - Built environment } \\
\text { - Transport } \\
\text { - Waste } \\
\text { - Water } \\
\text { - Well-being }\end{array}$ & $\begin{array}{c}\text { John Selwyn Gummer } \\
\text { Zac Goldsmith }\end{array}$ \\
\hline Social Justice & $\begin{array}{l}\text { - Family breakdown } \\
\text { - Educational failure } \\
\text { - Economic dependency } \\
\text { - Consumer debt } \\
\text { - Addictions (drink and drugs) } \\
\text { - Voluntary Sector }\end{array}$ & Iain Duncan Smith \\
\hline $\begin{array}{l}\text { National and } \\
\text { International } \\
\text { Security }\end{array}$ & $\begin{array}{l}\text { - National security and cohesion } \\
\text { - Defence } \\
\text { - Foreign affairs }\end{array}$ & $\begin{array}{l}\text { Dame Pauline } \\
\text { Neville-Jones }\end{array}$ \\
\hline $\begin{array}{l}\text { Globalisation and } \\
\text { Global Poverty }\end{array}$ & $\begin{array}{l}\text { - Overseas aid } \\
\text { - International trade } \\
\text { - Corruption } \\
\text { - International Development } \\
\text { - International conflict } \\
\text { - Department for International Development (future role of) }\end{array}$ & Peter Lilley \\
\hline
\end{tabular}

Figure 1 Policy review groups established by David Cameron.

Each of the six policy review groups comprised a 'board' or 'committee' (the nomenclature varying somewhat) of 6-12 members, many of whom were recruited from beyond the world of party politics, and selected instead on the basis of their relevant expertise, be that academic or as practitioner. Thus did the membership of the 'Public Service Improvement review group', for example, include a former leader of the Royal College of Nursing, a Professor of Education, a deputy head-teacher and a senior official from Help the Aged. Most of these policy review groups then established 'working parties' 
or sub-committees to examine the specific policy issues in detail, each of which was chaired by a board or committee member, and comprising further 'outside' experts. For example, under the aegis of the Quality of Life review group, the sub-committee on 'well-being' focused on six discrete issues: workrelated issues (work-life balance, occupational stress, flexible working); freedom and local democracy (devolving decision-taking and policy-making closer to local communities, use of referenda); mental health (anxiety, stress, depression); identity and belonging (shared social and cultural values, national identity); environment and community (open spaces, access to public amenities and community facilities, urban renewal, isolation in rural areas); consumption, down-shifting and materialism (securing a balance between material abundance or pursuit of wealth and personal happiness and 'quality of life'). Clearly, however, many of these topics were inextricably linked.

The six policy review groups were then expected to publish Interim Reports by the end of 2006, delineating the 'current position' or 'current problems' and 'likely future trends' regarding the issues under consideration, and offering potential solutions or policy proposals. These would form the basis of further deliberations by the review groups in lieu of final reports being presented to the Shadow Cabinet during the summer of 2007. These would provide the basis of more detailed policies to be honed and unveiled during the remainder of 2007 and throughout 2008, in readiness for the (envisaged) 2009 general election. Of course, as intimated earlier, it is this unveiling of more detailed and specific policies that is likely to exacerbate intra-party disagreements between those who genuinely share Cameron's 'modernizing agenda' and his determination to reposition the Conservatives on the centre ground, and those who continue to demand a restoration of Thatcherism and the concomitant placing of 'clear blue water' between the Conservative Party and Labour.

\section{Hostility to Cameron's Ideological Repositioning and Policy Modernization}

Certainly, David Cameron's determination to reposition the Conservatives ideologically, and adopt a range of distinctly un-Thatcherite policy positions or principles, has aroused increasing concern and contempt in some quarters of the Party. Although Cameron eventually won the December 2005 leadership contest quite comfortably - winning the ballot of grass-roots Conservative members by a 2:1 majority over David Davis — it was evident that Davis or Liam Fox had been the preferred choice of many Conservative MPs, to the extent that in the second ballot of the parliamentary party, Cameron's two rivals from the Right of the Party polled a combined total of 108 votes, while Cameron was supported by 90 Conservative MPs; in other words, Cameron won the largest number of votes among his parliamentary colleagues, but by no means a majority. 
Consequently, some of those Conservative MPs (along with one or two prominent Thatcherite peers in the House of Lords) and associated groupings on the backbenches uneasy about Cameron's advocacy of modernization during his leadership campaign, have subsequently felt their initial apprehension turning into a growing sense of alarm at both the pace and the direction of the new leader's reform agenda. Some of the most trenchant criticism of Cameron's approach has emanated from members of the Cornerstone Group, a body which counts at least 35 Conservative MPs among its 'friends and supporters', and which advocates a 'flat tax' of $22 \%$ and $£ 40$ billion in tax cuts, much stricter immigration controls, 'renegotiation' of Britain's membership of the EU, repeal of the Human Rights Act, and urges greater private sector involvement in public services such as the NHS. One of its leading members John Hayes, has complained that:

Sadly, some in our party have come to believe that by aping Blair, rather than studying Burke; by adopting the assumptions of the liberal elite, rather than recalling our Conservative roots; we might become as popular as our opponents. This route is likely to prove as disastrous electorally as it is unauthentic.... Conservatives must be both brave and authentic; brave enough to undertake the task of challenging the dominant liberal elite in all the spheres and institutions it has so effectively colonised, and authentic enough to regain the respect and loyalty of our natural supporter (Hayes, 2005, 7-8).

Another prominent Cornerstone Group member, Edward Leigh, was (according to a leaked memo from Cameron's Parliamentary Private Secretary) among a queue of Right-wing Conservatives who wanted to see Cameron 'to tell you to your face that you are the anti-Christ' (The Guardian, 12 July 2006). Certainly, Leigh has expressed concern that Cameron and his acolytes are expending so much time and energy pursuing the centre ground of British politics that they are in danger of neglecting the Conservatives 'core supporters'. Indeed, he warned that if Conservative 'modernizers' continue to ignore or 'turn down the volume' on issues such as immigration, the EU and tax cuts, then some erstwhile Conservative voters might switch to the British National Party or UKIP in frustration (The Times, 3 October 2006; see also Leigh, 2007, 14-15).

Certainly, an ICM opinion poll at the end of 2006 revealed that up to $14 \%$ of erstwhile Conservative supporters might switch to UKIP (The Guardian, 20 December 2006). While many - probably most — of those currently making such a 'threat' are unlikely to carry it out on polling day itself, even a few thousand Conservative defections to UKIP in the next general election could prove damaging to the Party. This is because there are currently 24 parliamentary seats in which the incumbent Conservative MP will be defending a majority of less than 2,000 (and in several of these, the majority is less than 
500), thereby leaving many of them particularly vulnerable to a challenge by UKIP. Indeed, UKIP is threatening to contest Conservative marginals at the next election (largely in response to Cameron's description of them, in spring 2006, as 'fruitcakes, loonies and closet racists, mostly'), in which case, their intervention might attract sufficient disgruntled Right-wing support away from the Conservative candidate or incumbent MP to enable the Labour or (more likely) Liberal Democrat candidate to win the seat, as occurred in four hitherto Conservative seats in the 2001 election.

In the meantime, one recent 'switcher' to UKIP was a former constituency chairman of ex-Conservative leader William Hague, Toby Horton, who insisted that he had not left the Conservative Party, but rather 'the Conservative Party left me'. In so defecting, Horton was effectively following in the footsteps of Mark Hudson, formerly chairman of the Sevenoaks (Kent) Conservative constituency association, and on the official Conservative candidates' list. Hudson justified his defection to UKIP on the grounds that David Cameron had turned the Conservative Party 'into something indistinguishable from New Labour', sentiments apparently shared by another Conservative defector to UKIP, Kevin Davidson Hall, a former Conservative candidate in Peterborough (The Times, 8 December 2006).

Meanwhile, Lord (Norman) Tebbit has wondered whether David Cameron is the Conservative's 'chairman Mao or Pol Pot, intent on purging even the memory and name of Thatcherism before building a New Modern Compassionate Green Globally Aware Party' (Tebbit, 2006a). Certainly, by the summer of 2006, Lord Tebbit was becoming increasingly unhappy at the direction in which David Cameron was leading the Party, warning that the 'present Conservative strategy is eroding its ultra-loyalist bedrock vote' and giving the strong impression that 'respectable working- and lower-middle-class supporters in the suburbs, country towns and villages are not quite good enough for the new "A" list, Notting Hill party' (Tebbit, 2006b; see also The Guardian 1 February 2006). Also attacking the Conservative modernizers' 'dinner party myth' that the centre ground provides the key to electoral success is Lord Saatchi, who has argued that the Conservative Party should once again embrace ideology rather than become slaves to pragmatism. Indeed, without actually naming David Cameron, Lord Saatchi has called on (genuine) conservatives 'to man the ideological barricades' against those who seek salvation on the centre ground (The Daily Telegraph, 20 November 2006).

Quite apart from their evident disapproval of his overall ideological orientation and political perspective, many of David Cameron's critics are particularly aggrieved at his refusal to endorse radical tax cuts, for a major reduction in taxation is as symbolic to many on the Conservative Right as 'clause IV' and a formal commitment to public ownership were to (Old) Labour's Left. As such, for some on the Right, Cameron's insistence that 
improving public services will take priority over tax cuts is tantamount to a betrayal of Thatcherism and what they perceive to be 'true Conservatism'. For such critics, the desire for substantial tax cuts has recently been underpinned by an infatuation with the 'flat taxes' adopted by some east European countries in recent years. Certainly, many Right-wing critics of Cameron's stance are convinced that radical tax cuts would prove highly popular with voters, particularly as the tax burden is widely deemed to have steadily - and stealthily - increased during Gordon Brown's 10-year tenure at the Treasury (see, e.g., Blackwell and Lea, 2006; Selsdon Group/No Turning Back Group, 2006).

Meanwhile, opinion among the Conservative's mass membership (polled a few days before Cameron's first anniversary as leader) appears to be fairly evenly divided, with $43 \%$ of members believing that the Party has gone too far in modernizing itself during the first year of Cameron's leadership, while $47 \%$ believe that the pace and scale of change have been about right. Only $11 \%$ of members currently want Cameron to go even further in modernizing the Conservative Party (http://conservativehome.blogs.com/torydiary/2006/12/ onethird_of_tor.html). Moreover, although a ballot of Party members in September 2006 yielded a vote of 60,859 votes in favour of the Built to Last statement of aims and values, with 4,787 votes against, the overall turnout constituted a mere $26.7 \%$ of the Party's grass-roots membership, meaning that only one in four Conservative Party members actually expressed their support for Cameron's 'modernizing manifesto'.

Yet, in spite of such hostility or indifference among the Party's grass-roots, and for all the criticisms expressed by some prominent Conservatives about the direction and speed of change, Cameron has evinced no signs of being deflected from his modernizing crusade. On the contrary, he has insisted, on numerous occasions, that the Conservative Party needs to undertake further and faster changes. He can claim that although (as noted above) $43 \%$ of Conservative members are unhappy with the modernization programme, $58 \%$ are either satisfied, or want him to proceed further or faster. Besides, quite apart from his apparently genuine commitment to a new mode of 'compassionate Conservatism' (much more sincere, it seems, than its brief advocacy by each of his three predecessors), Cameron is evidently convinced that while a few Rightwing malcontents might defect to UKIP (losing support to the BNP is less of an issue for the Conservatives, because electoral advances for the latter tends to derive primarily from disaffected working class Labour voters), their numbers will be vastly outweighed by the voters returning to the Conservative fold having abandoned it in the last three general elections.

More specifically, on the symbolically crucial issue of taxation, Cameron has refused to yield to consistent Right-wing demands for a pledge on tax cuts. For example, the Conservative's tax commission, co-chaired by John Redwood and 
Lord (Michael) Forsyth, published its 175-page report in the autumn of 2006 and proposed tax cuts totalling $£ 21$ billion, while at about the same time Edward Leigh was insisting that: 'If the Conservative Party does not promise tax cuts then it's nothing'. Yet, Cameron and his Shadow Chancellor, George Osborne, were swift and emphatic in their rejection of such demands for such cuts in taxation, with Cameron insisting that the Party 'can't make promises we can't keep', and vowing that he would not be 'pushed around' on the issue (http://news.bbc.co.uk/1/hi/uk_politics/5397426.stm, 2 October 2006). Such defiance was echoed, almost word-for-word, by George Osborne's speech at the Conservative's 2006 conference. Nor has Cameron evinced any subsequent inclination to yield to Right-wing demands, thereby ensuring that it remains a key issue in the Party, and is likely to do so until the general election, and probably beyond. The Conservative Right view tax cuts as crucial to placing 'clear blue water' between themselves and New Labour, while Cameron clearly views a corresponding refusal to promise tax cuts as integral to his determination to signify a break with Thatcherism. Cameron clearly envisages that confronting the Conservative Right over tax cuts will enhance his modernizing image to centrist voters in much the same way as Blair once confronted the Labour Left over Clause IV in order to signify his modernizing credentials to Middle England.

\section{'Modernizing' the Conservative Party}

In conjunction with the promotion of a much more socially liberal mode of Conservatism, coupled with the enthusiastic advocacy of 'quality of life' issues, Cameron has also sought to render the Conservative Party more socially representative (and inter alia electorally attractive) by seeking the adoption of more women and ethnic minority candidates to contest the next general election. Cameron deemed it a 'scandal' that there were only 17 women Conservative MPs in the post-2005 Parliament, while a mere two of the Party's MPs emanated from ethnic minority communities, and pointed out that widening recruitment and increasing social diversity within the Conservative Party was not only about fairness and representativeness, but also about preventing the Party from 'missing out on huge amounts of talent' (http:// news.bbc.co.uk/1/hi/uk_politics/5269750.stm, 21 August 2006).

Cameron's attempt at ensuring that a more socially diverse and representative range of Conservative parliamentary candidates were adopted in readiness for the next election entailed the drafting of an 'A list' of candidates, of whom $50 \%$ would be women and $10 \%$ from ethnic minority backgrounds. It was envisaged that the list would be 'consulted' by local Conservative associations in 'winnable seats', when they were selecting a candidate to contest the next election. 
In this context, Cameron's initial efforts enjoyed only limited success (for reasons noted below), to the extent that during the first half of 2006, women candidates were adopted by Conservative constituency associations in $32 \%$ of winnable seats, while in almost half of the constituencies involved in candidate selection, a local Conservative was adopted in preference to those on the 'A list' presented by Central Office. Consequently, in August 2006, an evidently frustrated Cameron insisted that local Conservative associations in 'target seats' should ensure that on a short-list of four candidates, at least two should be women, after which the final selection would be made by the constituency's executive council. The council's choice would then be presented to a special meeting of the constituency party members, the expectation being that they would endorse the selected candidate. At the same time, Cameron sought to increase the proportion of women on the 'A list' from 50 to $60 \%$, and hinted that if more women candidates were not adopted he might consider imposing all-women short-lists on recalcitrant Conservative constituency associations (The Guardian, 21 August 2006).

However, stipulating that at least $50 \%$ of candidates on the final constituency short-list should be women would not guarantee that local Conservative associations actually selected one of those women when making their final choice, a point illustrated in Folkestone during July 2006, when two of the three candidates on the final short-list to contest Michael Howard's seat (when he stands down at the next election) were women, but it was nonetheless the male candidate who was finally adopted.

By November 2006, a total of 39 candidates had been selected for seats since David Cameron's introduction of the 'A-list', of whom $15(38.5 \%)$ were women, $24(61.5 \%)$ were men, and $2(5 \%)$ emanated from ethnic minority backgrounds. Moreover, of these 39 candidates, 23 (59\%) were selected from the A-list, while $16(41 \%)$ were local candidates (the Daily Telegraph, 10 November 2006; for full details of candidate selections in 2006, see http:// conservativehome.blogs.com/goldlist/who_has_been_selected_so_far/index.html). November also saw David Cameron dismiss Bernard Jenkin from his post as Deputy Conservative Chairman with special responsibility for candidate selection, with a key 'modernizer', John Maples, replacing him, strongly suggesting that Cameron himself was not satisfied with the pace of change in this sphere.

\section{Resistance to Reforming and Widening Recruitment}

This relatively slow pace of change is due to a combination of apparently entrenched local-level Conservative prejudices against the adoption of more women and ethnic minority parliamentary candidates, and the extent to which local Conservative constituency associations have jealously sought to guard 
their relative autonomy over candidate section, particularly against the imposition by the parliamentary leadership or Central Office of anything resembling a 'quota system' (see, e.g., the website of the Campaign for Conservative Democracy, http://www. copov.org.uk, which has consistently denounced the 'A-list' and Central Office 'interference' in candidate selection). Together, these two characteristics of constituency-level Conservatism threatened to pose a significant obstacle to Cameron's attempt at crafting a more socially pluralist and representative parliamentary Conservative Party. Certainly, some Conservative constituency associations seemed to view the emphasis on adopting more women and ethnic minority candidates as a manifestation of 'political correctness gone mad'; something which they would expect from the Labour Party and the Liberal Democrats, but which they apparently deemed alien to Conservative traditions.

Consequently Cameron's efforts at ensuring that a more socially diverse and representative range of parliamentary candidates are adopted has aroused similar antipathy to that engendered by his ideological repositioning of the Conservatives, and invariably from the same quarters of the Party too, with some Conservatives still seeming to share the view expressed by Nicholas Soames a few years ago, that the Conservative Party should cease its 'mad obsession with gays, blacks and women' (The Daily Telegraph, 19 August 2002). One critic of Cameron's approach in this sphere, John Hayes, has alleged that the A-list of parliamentary candidates is a "product of the bizarre theory of people who spend too much time with the pseuds and poseurs of London's chichi set and not enough time in normal Britain', a view apparently shared by several Conservative backbenchers (The Guardian, 12 July 2006). Another prominent critic is Anne Widdecombe, who has described the A-list as 'diabolical', and suggested that the concern to adopt more women, ethnic minority and gay candidates would effectively mean that 'if you are a white, male, Christian, heterosexual, there are going to be very few places for you on this list' (The Sunday Times, 29 January 2006). Meanwhile, shortly before his sudden death, Eric Forth was threatening to defer his (anticipated) retirement as MP for Bromley and Chislehurst at the next election, in order to prevent the 'imposition' of candidate from Central Office's 'A-list', to which Forth was bitterly opposed (The Times, 19 May 2006).

\section{Modest Recovery in the Opinion Polls}

In the first 4 months of Cameron's leadership, the Conservative Party evinced only a very slight recovery in the opinion polls. Those Conservatives who had understandably anticipated a surge in the Party's public popularity following Cameron's election were to be disappointed and frustrated at the modesty of 
the Party's increased support. Indeed, from January to April 2006, Conservative support actually declined from an initial $38-34 \%$, yielding leads over Labour of just $2-3 \%$, in spite of public perceptions about the Blair Government's perceived failure 'to deliver' on a range of policy pledges most notably crime, education, and health, along with continuing public unease about Britain's military involvement in Iraq - coupled with declining levels of trust in Tony Blair per se, particularly in the context of the Iraq war.

However, an impressive performance in May's local government elections (when the Conservatives attained $40 \%$ of votes cast, had the highest number of Conservative councillors elected since 1990, and ended up in control of 68 councils compared to Labour's 29, and the Liberal Democrats' 11) heralded some notable advances in the Conservative Party's opinion poll ratings during the following months, as illustrated by Figure 2.

A Conservative lead over Labour of $5 \%$ in June was surpassed by a $9 \%$ lead in August, and a 10\% lead in October. However, on both occasions, the following month saw the Conservative poll lead fall back to 4 and $5 \%$, respectively, suggesting that the recovery under David Cameron is proving particularly susceptible to short-term factors and fluctuations, to the extent that the Party's average lead for the 12 months to December 2006 was fractionally over 5\%. Cameron himself has naturally depicted all of these polls

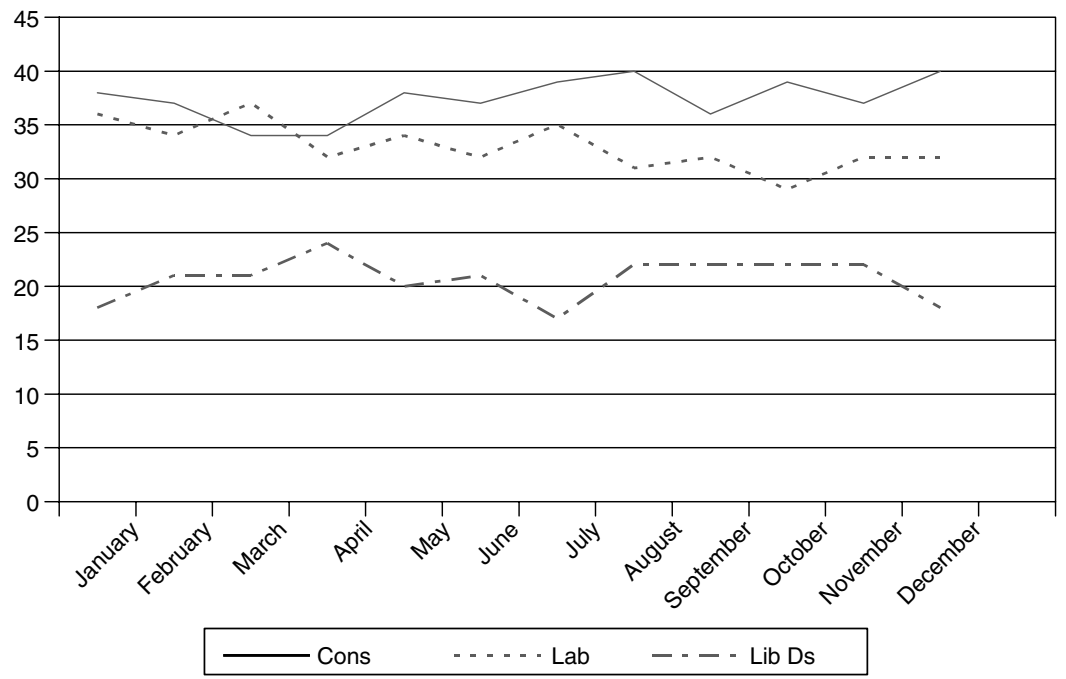

Figure 2 The Conservative Party's opinion poll ratings January-November 2006. Source: Extrapolated from http://www.icmresearch.co.uk/reviews/latest-polls.asp. 
as a vindication of his modernization agenda. When the polls show an increased Conservative lead, he views this as evidence that he is leading the Party back from the political wilderness and reconnecting with moderate or centrist British voters, while narrower or diminished poll leads are deemed to indicate the need for further and faster modernization in order to persuade sceptical voters that the Conservative Party is genuinely changing and moving back towards the centre ground.

While 2006 clearly represents a significant improvement in the Conservative Party's poll ratings since 1992, seven particular points need to noted in order to place this recovery in perspective. Firstly, it is widely acknowledged that such polls concerning voting intentions generally entail a 3\% margin of error, in which case while the Conservative Party's lead over Labour might be somewhat greater than the headline figures sometimes suggest, it could just as readily be rather less, possibly to the extent of being virtually cancelled out.

Secondly, due to slightly varying methodologies, some opinion polls (conducted by other polling companies) have occasionally indicated Labour leads over the Conservatives during 2006. For example, a YouGov poll in April 2006 gave Labour a 2\% lead over the Conservatives (The Daily Telegraph, 21 April 2006), while an Ipsos-MORI poll in October 2006 similarly suggested a $2 \%$ lead for Labour, this representing an increase of $1 \%$ from September (http://www.ipsos-mori.com/political/archive). Meanwhile, whereas an ICM poll in December 2006 suggested that the Conservatives had extended their lead over Labour to 8\% (The Guardian, 20 December 2006), a Populus poll published a few days earlier suggested that the Conservatives' lead over Labour had actually fallen to a mere 1\% (The Times, 12 December 2006).

The fluctuating nature of the Conservative's opinion poll ratings thus suggests that the Party has not yet established a convincing or consistent lead over the Labour Party, even though they have undoubtedly become more popular under David Cameron's leadership. Certainly, their poll leads have not been remotely comparable to those attained by the Labour Party during the mid-1990s following Tony Blair's election as leader (although, admittedly, these were exceptionally high), when the incumbent government was itself widely perceived to be increasingly incompetent and mired in 'sleaze'.

Thirdly, but following directly on from these two points, given the degree of disillusionment with the Labour Government in general, and the loss of trust in Tony Blair in particular, David Cameron's Conservatives really ought to have established a more commanding and enduring lead since December 2005. That they have so far failed to do so clearly suggests that public disenchantment with the present occupant of 10 Downing Street and his jaded-looking administration has not yet translated into a groundswell of sustained support for the Cameron-led Conservative Party. 
Fourthly, but again, following directly on from the previous observation, the leads that David Cameron's Conservatives have recently enjoyed in many opinion polls are relatively low, particularly given the tendency for most governments to suffer from 'mid-term blues', before rallying somewhat in the next general election itself. After all, even during its nadir in the 1980s, the Labour Party variously enjoyed opinion poll leads over Margaret Thatcher's Conservatives, yet these did nothing to prevent crushing election defeats in 1983 and 1987. For example, in 1980 and 1981, Michael Foot's Labour Party averaged (MORI) poll leads of 7 and 6\%, respectively, over Margaret Thatcher's Conservatives - and in several individual months, attained doublefigure leads - yet in the 1983 general election itself the Conservatives won with a $16 \%$ lead over Labour (although the 'Falklands effect' certainly played a major part in the Conservative's recovery). Meanwhile, although Labour's average (MORI) poll lead over the Conservatives was $2.5 \%$ in 1986, and actually reached $8 \%$ in May of that year, Labour still suffered another heavy defeat in the following year's general election, when it polled $11 \%$ fewer votes than the Conservatives. Similarly, Labour's average lead of $2.5 \%$ in (MORI) polls between October 1991 and March 1992 (inclusive) was insufficient to prevent a fourth Conservative victory in the 1992 election, which they won with an $8 \%$ lead over Labour. By contrast, prior to Labour's emphatic victory in 1997, when it polled $13 \%$ more votes than the Conservatives, it had enjoyed average leads of 30 and $25 \%$ in 1995 and 1996 respectively. Indeed, the fact that Labour's eventual lead in the 1997 election was only about half of what it had been throughout the previous two years reiterates the point that the singledigit leads over Labour thus far enjoyed by Cameron's Conservatives are highly unlikely to be sufficient to deliver outright victory in the next general election.

Following on from this last point is a fifth caveat concerning the Conservative's 2006 recovery in the opinion polls, namely the tendency for the governing party, on polling day itself, to recover at least some of the support lost during the 'mid-term blues'. For example, in January 1987, the Conservative Party's support in a (MORI) poll stood at 39\%, but recovered to $43 \%$ on election day in June, while Labour's support declined by $6 \%$ during the same period. A similar trend manifested itself in 1992, when the Conservative's $39 \%$ rating in a MORI poll during February rallied to $43 \%$ in the April election per se, while Labour's support declined by 5\%. Even in the 1997 election, although John Major's Conservative Government suffered a crushing defeat, its share of the vote was nonetheless $3 \%$ higher on polling day in April than it had been in a MORI poll conducted a month earlier, while Labour's support fell by $11 \%$ during this period. Again, the clear implication is that the lead over Labour thus far enjoyed by Cameron's Conservatives appears very fragile, and unless it can be substantially increased - and 
sustained - during the next couple of years, is highly likely to dissipate somewhat when the next general election is held.

Sixthly, as noted earlier, David Cameron has spent most of his first year as Conservative leader talking in terms of a gentler, more compassionate and socially inclusive mode of Conservatism, whereby his Party will reposition itself on the centre ground. This has undoubtedly proved attractive to some voters, but Cameron may well discover that once he and his senior Conservative colleagues begin to enunciate more specific policies during the next couple of years, some of this renewed support might diminish (although, of course, it is also conceivable that greater policy specificity might actually attract support which is currently being withheld pending greater clarity about what the Conservative Party will actually offer under Cameron's leadership). Certainly, there is a distinct possibility that when more specific policies are formally adopted - particularly if they genuinely derive from the 'one nation' principles articulated by Cameron - then intra-Party disagreements will once again manifest themselves, and suggest to the electorate that the Conservative Party is not united behind the 'Cameron project' of ideological repositioning and policy modernization. We have already noted the misgivings and mutterings on the Conservative Right over Cameron's professed objectives and principles, and these dissenting voices are likely to become more shrill and strident if the actual policies eventually promoted by Cameron and his senior colleagues maintain the clear break with Thatcherism which the rhetoric so far has promised. If this proves to be the case, then Labour and the Liberal Democrats will doubtless seize the opportunity to persuade voters that beyond David Cameron and his warm words lurks the same 'nasty' Conservative Party 'what lies behind the smile?'

At the very least, if the Conservative Right become more outspoken and critical in the context of genuinely 'one nation' policies being adopted by Cameron and his colleagues, then the electorate might well adjudge the Conservative Party to be seriously divided, and thus still unfit to govern. Certainly, a YouGov poll published in autumn 2006 suggested that 25\% of voters thought that the Conservative Party was more divided than Labour, compared to $24 \%$ deeming Labour to be more divided than the Conservatives (The Sunday Times, 24 September 2006), and although this is obviously an extremely narrow difference, the former may well increase (to the detriment of Cameron's Conservatives) if, and when, greater policy specificity engenders an increase in intra-Party disagreement and disunity.

The seventh and final caveat which needs to be noted when observing the Conservative Party's 2006 opinion poll leads is that much of this relative popularity seems to be derived from David Cameron himself (and the 'one nation' discourse he deploys), rather than any discernible increase in public liking for the Conservative Party per se. One manifestation of this concerns 


\begin{tabular}{lrccc}
\hline & Centre & $\begin{array}{c}\text { Slightly right- } \\
\text { of centre }\end{array}$ & $\begin{array}{c}\text { Fairly right- } \\
\text { wing }\end{array}$ & $\begin{array}{c}\text { Very right- } \\
\text { wing }\end{array}$ \\
a) Conservative Party & $7 \%$ & $13 \%$ & $24 \%$ & $16 \%$ \\
b) David Cameron & $13 \%$ & $24 \%$ & $18 \%$ & $7 \%$ \\
c) Yourself & $23 \%$ & $11 \%$ & $8 \%$ & $4 \%$
\end{tabular}

Figure 3 Perceptions of ideological position; Respondents asked: 'Where would you place (a) the Conservative Party (b) David Cameron (c) yourself ideologically?

Source: YouGov/The Daily Telegraph, 2 October 2006.

voters' perceptions about ideological positioning, as illustrated by Figure 3. It is evident not only that the Conservative Party is generally perceived to be rather more Right-wing than Cameron himself, but that both are deemed to be to the Right of most voters. These figures suggest that many voters remain unconvinced that the Conservative Party itself has changed, even though many of them are favourably disposed towards David Cameron himself and admire what he is seeking to achieve politically. As the Conservative Party chairman, Francis Maude acknowledges: 'People really like David Cameron... . They are not yet convinced that the party has changed' (The Guardian, 7 April 2006).

Against these sobering caveats, though, David Cameron might draw comfort from three other broad findings revealed by various opinion polls conducted during 2006. Firstly, a number of polls have suggested that David Cameron may fare rather better if and when Gordon Brown succeeds Tony Blair. For example, as Figure 4 illustrates, an ICM poll commissioned by The Guardian in September 2006 reveals that Cameron commands significant leads over Gordon Brown on personal qualities, most notably honesty and collegiality, but rather narrower leads on the questions of perceived prime ministerial potential, and the likelihood of taking Britain in the right direction (an admittedly nebulous notion). However, Gordon Brown polled more highly than Cameron in terms of being trusted to take the right decisions in tough circumstances (see also the results of a 'Communicate Research' poll into voters' views about Cameron and Brown published in The Independent, 28 December 2006).

Two months later, another poll (by MORI) suggested that if a general election was held in November 2006 with Tony Blair still leading Labour, his Party would secure $32 \%$ of votes cast, while the Conservatives would win $37 \%$. However, when asked how they would vote if Gordon Brown had now replaced Blair, Labour's support remained static, while the Conservative's support increased to $40 \%$, primarily due to a switch from the Liberal Democrats (The Guardian, 22 November 2006). 


\begin{tabular}{|c|c|c|c|}
\hline Question & $\begin{array}{l}\text { David } \\
\text { Cameron }\end{array}$ & $\begin{array}{l}\text { Gordon } \\
\text { Brown }\end{array}$ & $\begin{array}{l}\text { Cameron's } \\
\text { lead }\end{array}$ \\
\hline $\begin{array}{l}\text { Who has most potential as a } \\
\text { Prime Minister? }\end{array}$ & $35 \%$ & $32 \%$ & $+3 \%$ \\
\hline $\begin{array}{l}\text { Who is most likely to take Britain } \\
\text { in the right direction? }\end{array}$ & $31 \%$ & $26 \%$ & $+5 \%$ \\
\hline $\begin{array}{l}\text { Who is most likely to make the } \\
\text { right decisions when the going } \\
\text { gets tough? }\end{array}$ & $25 \%$ & $32 \%$ & $-7 \%$ \\
\hline $\begin{array}{l}\text { Who is most likely to be able } \\
\text { to work with Cabinet colleagues? }\end{array}$ & $39 \%$ & $22 \%$ & $+17 \%$ \\
\hline Who is the most honest? & $27 \%$ & $19 \%$ & $+8 \%$ \\
\hline $\begin{array}{l}\text { Who is likely to have the more } \\
\text { pleasant personality? }\end{array}$ & $52 \%$ & $17 \%$ & $+35 \%$ \\
\hline
\end{tabular}

Figure 4 Public evaluations of David Cameron and Gordon Brown. Source: ICM/The Guardian, 22 September 2006.

The second source of comfort to be gleaned by David Cameron in the context of the often modest and inconsistent opinion poll leads over a tired and discredited Labour Government is his popularity among women voters. Women have traditionally been more inclined to vote Conservative than men, but this tendency was reversed by the advent of New Labour. However, David Cameron seems to be winning back some of these women voters, particularly in the context of their disillusionment with Tony Blair and apparent dislike of Gordon Brown. For instance, a Populus poll published in November 2006 revealed that whereas men were evenly divided in their support for the Conservatives and Labour (34\% each), women preferred the Conservatives by $37-31 \%$. Moreover, when respondents were asked how they would vote if Gordon Brown had finally replaced Tony Blair, the Labour Party actually enjoyed a $37-34 \%$ lead over the Conservatives among men, whereas only $30 \%$ of women said they would vote for a Brown-led Labour Party, compared to the $42 \%$ who opted for the Conservatives. In other words, a Labour Party led by Gordon Brown would enjoy a 3\% lead among men, but suffer a $12 \%$ deficit among women (The Times, 7 November 2006; see also The Sunday Times, 24 December 2006). 
The third source of comfort offered to David Cameron by some opinion polls concerns key policy issues, with a Guardian/ICM poll in May 2006 revealing that the Conservatives had established a $2 \%$ lead - 26-24\% - over Labour on the question of which party was 'best' on the NHS (previously a 'Labour issue' virtually since the NHS was founded in 1948), with a similar lead - 30-28\% - on education (another policy issue on which Labour has generally enjoyed a strong lead, at least since the 1980s). However, given that 2006 had witnessed countless media reports of recurrent crises in the NHS, particularly with regard to massive deficits and consequent ward closures and redundancies, it might have been expected that the Conservatives would have established a rather bigger lead, but in the aforementioned absence of greater policy specificity, voters are not sure how the Conservatives would tackle the ongoing problems of the NHS, so that widespread public concern over Labour's chronic mismanagement only translates into a narrow lead for the Conservatives on the issue. Meanwhile, with the economy still buoyant and house prices still increasing steadily, Labour led the Conservatives on stewardship of the economy by 37-30\% (The Guardian, 24 May 2006), suggesting that the Conservatives have yet to regain the reputation for 'economic competence' which they lost due to 'Black Wednesday' in September 1992.

\section{Conclusion}

David Cameron has toiled tirelessly during his first year as Conservative leader to reposition the Party ideologically, and revive the 'one nation' strand which atrophied during the 1980s and 1990s. In so doing, he has explicitly eschewed Thatcherism, and effectively apologized for many aspects of it, while explicitly abandoning many of the policies implemented during the Thatcher-Major premierships. Cameron has sought to depict the Conservatives as a more socially tolerant and inclusive Party, as evinced by the downgrading of such emotive issues as Europe, immigration, and single parents, in favour of quality of life issues, most notably achieving a better work-life balance, doing much more to assist the 'socially dispossessed', and protecting the environment in an era of accelerating climate change and global warming. Cameron and his fellow Conservative modernizers have also emphasized that improvements in the public sector require the forging of a new partnership with the professionals employed within these services, and, moreover, insisted that such improvements must take priority over tax cuts.

Ostensibly, this ideological repositioning and political re-branding has been highly successful, as evinced by the Conservative Party's marked improvements in the opinion polls throughout most of 2006, when they obtained their first 
sustained poll leads since September 1992. Cameron's first year also coincided with a period in which the Blair Government looked increasingly arrogant, jaded, incompetent and out-of-touch, faced as it was by continued loss of trust and hostility over the Iraq war, a financial crisis in the NHS leading to redundancies and ward closures, and Tony Blair's alleged involvement in a 'cash for peerages' scandal. Moreover, although Ministers routinely cited official statistics suggesting that crime was falling, the public remained convinced that 'street crime' was increasing dramatically, an impression underpinned by a number of high-profile fatal stabbings during the last year, linked to the apparent development of a macho 'knife culture' among parts of Britain's urban underclass.

However, more careful consideration suggests that the Conservative Party's recovery during the first year of David Cameron's leadership is actually rather fragile, and is unlikely to deliver victory in the next general election. The Conservative Party's leads in the opinion polls during 2006 were erratic, and often rather modest. Certainly, the leads were neither large enough nor consistent enough to suggest that the Conservatives will win a clear majority at the next general election. After all, throughout 1980 and 1981, the Labour Opposition led by Michael Foot averaged leads of $7-8 \%$ in the opinion polls, but still suffered a crushing defeat in the 1983 election (although the Thatcher Government was undoubtedly greatly assisted by the 'Falklands factor'). Labour also performed relatively well in numerous local elections during the 1980s, but such successes counted for nothing in general elections. To be serious contenders for governmental office at the next general election, David Cameron's Conservative Party really ought to be securing consistent doubledigit leads (at least in the $14-15 \%$ range) at this stage of the electoral cycle, particularly given the problems that have afflicted the Labour Government during 2006, and how discredited and distrusted Tony Blair has become. Moreover, by the next general election, Tony Blair will no longer be Prime Minister, and his successor might imbue the Government with a renewed sense of vitality. It is also likely that Iraq will no longer be such a source of antipathy towards the Labour Government by the time the next general election is held. Hence the assertion that Cameron's Conservative Party has enjoyed only a rather fragile and unconvincing recovery since December 2005, and that at least some of this is attributable to short-term factors. If the Conservatives are to win the next general election, they really need to secure rather larger and more stable leads in the opinion polls.

A further indication of the fragility of the Conservative's recovery in the polls during 2006 was the result of the Bromley and Chislehurst by-election in May, when the Party's vote was almost halved from the general election held just 12 months previously, thereby reducing a majority of 13,342 in 2005 to just 633 in 2006. Although Conservative modernizers might dismiss such a result as 
being 'unrepresentative', due to the low (24\%) turnout in a traditionally safe Conservative seat, it should be noted that both the Liberal Democrats and UKIP actually polled more votes than in 2005 .

Another reason for scepticism about the extent to which the Conservatives have genuinely recovered from the problems that have beset the Party since 1992 is that David Cameron and his fellow Conservative modernizers have (deliberately) avoided making many specific policy pledges thus far, for perfectly sound political reasons that this article has duly noted. However, the initial popularity and apparent revival which Cameron has engendered by repositioning the Conservative Party ideologically, and by emphasising his commitment to previously-neglected (by most Conservatives) policy issues such as 'work-life balance' and environmental protection, may be undermined once specific policies are unveiled. If the subsequent policies are not deemed to match the expectations that Cameron has raised about a new mode of Conservatism for the early 21 st century, the voters may conclude that the Conservative Party is not really offering anything new or novel, whereupon it will probably lose much of the additional support it has recently attracted. Yet, if Cameron genuinely does offer socially liberal 'one nation' policies, this is likely to promote further fury on the Party's unreconstructed Right, thereby reviving impressions of an internally divided party which is unfit to govern. Labour (and the Liberal Democrats) would almost certainly exploit any such divisions by warning voters that if the Conservatives were elected, Cameron would be 'held hostage' by the Conservative Right, just as John Major often appeared to be. Furthermore, if Cameron does adhere to a 'one nation' approach, then some of the additional electoral support consequently attracted or regained might well be negated by disgruntled Right-wing Conservatives switching to UKIP, which could prove costly in a number of marginal seats.

Ultimately, therefore, this article maintains that David Cameron's Conservative Party still has a political mountain to climb. Although Cameron himself is certain about the route to follow in order to reach the peak, some of his colleagues remain, and will continue to remain, unconvinced that this is the correct path to follow. Meanwhile, although Cameron and his acolytes are understandably pleased with how much ground they have so far travelled, and how much progress they have made, those observing from a distance can see that they are barely beyond base camp.

\section{References}

Bechhofer, F. and Elliott, B. (1981) 'Petty Property: The Survival of a Moral Economy', in F. Bechhofer and B. Eliott (eds.) The Petit Bourgeoisie: Comparative Studies of the Uneasy Stratum, New York: Macmillan. 
Blackwell, N. and Lea, R. (2006) From Principles to Policy: What an Alternative Manifesto Should Say, London: Centre for Policy Studies.

Blake, R. (1985) The Conservative Party from Peel to Thatcher, London: Methuen.

Cameron, D. (2005) 'Change our political system and our lifestyles', The Independent, 1 November.

Conservative Party (2006) Built to Last: The Aims and Values of the Conservative Party, London: London Conservative Party.

Critchley, J. and Halcrow, M. (1998) Collapse of the Stout Party: The Decline and Fall of the Tories, London: Indigo.

Denham, A. and Dorey, P. (2006) 'A tale of two speeches? The Conservative leadership election of 2005', Political Quarterly 77(1): 35-42.

Denham, A. and O'Hara, K. (2007) 'The three "mantras": "Modernization” and The Conservative Party', British Politics 2(2): 167-190.

Dorey, P. (1996) 'Exhaustion of a tradition: The death of "one nation" Toryism', Contemporary Politics 2(4): 47-65.

Dorey, P (1999) 'Despair and Disillusion Abound: The Major Premiership in Perspective', in P. Dorey (ed.) The Major Premiership: Politics and Policies Under John Major, 1990-1997, Basingstoke: Macmillan.

Dorey, P (2002) 'The Conservatives in Opposition, 1997-2001', in S. Lancaster (ed.) Developments in Politics 12, Ormskirk: Causeway Press.

Dorey, P. (2003) 'Conservative Policy Under William Hague', in M. Garnett and P. Lynch (eds.) The Conservatives in Crisis, 1997-2001, Manchester: Manchester University Press.

Dorey, P (2004) 'Iain Duncan Smith's Conservative Party', in S. Lancaster (ed.) Developments in Politics 14, Ormskirk: Causeway Press.

Eccleshall, R. (1990) English Conservatism Since the Restoration: An Introduction and Anthology, London: Unwin Hyman.

Freedland, J. (2005) 'Enough of this love-in: Bush was a compassionate Conservative too', The Guardian, 7 December.

Gamble, A. (1974) The Conservative Nation, London: Routledge and Kegan Paul.

Gamble, A. (1998) The Free Economy and the Strong State: The Politics of Thatcherism, Macmillan: Basingstoke.

Gilmour, I. and Garnett, M. (1997) Whatever Happened to the Tories: The Conservatives Since 1945, London: Fourth Estate.

Green, D. (2005) 'One Nation', in K. Hickson (ed.) The Political Thought of the Conservative Party Since 1945, Basingstoke: Palgrave Macmillan.

Greenleaf, W.H. (1983) The British Political Tradition, Volume Two: The Ideological Heritage, London: Routledge.

Hall, S. (1980) Drifting into a Law and Order Society, London: Cobden Trust.

Hall, S., Critcher, C., Jefferson, T., Clarke, J., Roberts, B. (1978) Policing the Crisis: Mugging, the State, and Law and Order, New York: Macmillan.

Hayes, J. (2005) 'Being Conservative', in The Cornerstone Group of Conservative MPs Being Conservative: A Cornerstone of Policies to Revive Britain, London: Cornerstone Group.

Leigh, E. (2007) 'Triangulation or strangulation?', The House Magazine 32(1205): 14-15.

Perry, B. and Dorrell, S. (2006) The Well-Being of the Nation: Interim Report of the Public Service Improvement Policy Group, London: London Conservative Party.

Ramsden, J (1999) An Appetite for Power: A History of the Conservative Party Since 1830, New York: HarperCollins.

Sanders, D. (2006) 'Reflections on the 2005 General Election: some speculations on how the Conservatives can win next time', British Politics 1(2): 170-194.

Seldon, A. (1994) 'Conservative Century', in A. Seldon and S. Ball (eds.) Conservative Century: The Conservative Party since 1900, Oxford: Oxford University Press. 
Selsdon Group/No Turning Back Group (2006) The Case for Lower Taxes, London: Selsdon Group/No Turning Bank Group of MPs.

Tebbit, N. (2006a) 'Change is needed, but be careful, Mr Cameron', The Daily Telegraph, 8 January.

Tebbit, N. (2006b) 'Cameron is alienating his voters”, The Spectator, 29 July 2006.

Wheatcroft, G. (2005) The Strange Death of Tory England, London: Penguin Allen Lane. 